\title{
A General Method for the Synthesis of Nonracemic trans-Epoxides: Concise Syntheses of trans-Epoxide Containing Insect Sex Pheromones
}

\author{
Baldip Kang, Robert Britton* \\ Department of Chemistry, Simon Fraser University, 8888 University Drive, Burnaby, \\ British Columbia, V5A 1S6, Canada
}

\section{Supporting Information}

Experimental Procedures pages 1-12

${ }^{1} \mathrm{H}$ and ${ }^{13} \mathrm{C}$ NMR Spectral Data pages 13-23

\section{General}

All reactions described were preformed under an atmosphere of dry argon using oven-dried glassware unless otherwise specified. THF, $\mathrm{Et}_{2} \mathrm{O}, \mathrm{CH}_{2} \mathrm{Cl}_{2}$ were used directly from an MBraun Solvent Purifier System (MB-SP Series). Commercial anhydrous EtOH (reagent grade) was used without further purification. Cold temperatures were maintained by the use of following reaction baths: $0{ }^{\circ} \mathrm{C}$, ice-water; $-30{ }^{\circ} \mathrm{C}$, ethyl acetate-ethanol; -78 ${ }^{\circ} \mathrm{C}$, acetone-dry ice. Flash chromatography was carried out with 230-400 mesh silica gel (E. Merck, Silica Gel 60) following the technique described by Still. ${ }^{1}$ Concentration of solvents was accomplished with a Buchi rotary evaporator using acetone-dry-ice condenser and removal of trace solvents was accomplished with a Welch vacuum pump.

Gas chromatography (GC) analysis was preformed on a Hewlett Packard model 6890 gas chromatograph, equipped with a flame ionization detector and a custom made fused silica column with a 1:1 mixture of heptakis-(2,6-di- $O$-methyl-3-O-pentyl)- $\beta$ cyclodextrin and OV-1701.,3

NMR spectra were recorded using deuteriochloroform $\left(\mathrm{CDCl}_{3}\right)$ as the solvent. Signal positions $(\delta)$ are given in parts per million from tetramethylsilane $(\delta 0)$ and were measured relative to the signal of the solvent $\left(\mathrm{CDCl}_{3}: \delta 7.26,{ }^{1} \mathrm{H} \mathrm{NMR} ; \delta 77.0,{ }^{13} \mathrm{C}\right.$ NMR). Coupling constants ( $J$ values) are given in Hertz $(\mathrm{Hz})$ and are reported to the nearest $0.1 \mathrm{~Hz} .{ }^{1} \mathrm{H}$ NMR spectral data are tabulated in the order: multiplicity (s, singlet; d, doublet; $\mathrm{t}$, triplet; $\mathrm{m}$, multiplet), number of protons, coupling constants. Proton nuclear magnetic resonance $\left({ }^{1} \mathrm{H}\right.$ NMR) spectra were recorded on a Bruker Avance 600 equipped with a QNP cryoprobe $(600 \mathrm{MHz})$ or Varian Inova $500(500 \mathrm{MHz})$. Carbon nuclear magnetic resonance $\left({ }^{13} \mathrm{C}\right.$ NMR) spectra were recorded on a Bruker Avance 600 equipped with a QNP cryoprobe $(150 \mathrm{MHz})$ or Varian Inova $500(125 \mathrm{MHz})$.

Infrared (IR) spectra were recorded on a MB-series Bomem/Hartman \& Braun Fourier transform spectrophotometer with internal calibration as films between sodium chloride plates. Only selected, characteristic absorption data are provided for each compound. 
Chemical ionization (CI) mass spectra were recorded on a Varian 4000 mass spectrometer at $70 \mathrm{eV}$. High-resolution electron impact (EI) and fast atom bombardment (FAB) mass spectra were recorded on a JEOL JMS-AX505HA mass spectrometer at 3 $\mathrm{kV}$. Optical rotation was measured on a Perkin Elmer Polarimeter 341 at $589 \mathrm{~nm}$.

\section{Preparation of (2R)-2-chloropentanal (10)}

\section{Procedure A:}

To a cold $\left(0{ }^{\circ} \mathrm{C}\right)$, stirred solution of pentanal $(172 \mathrm{mg}, 2.0 \mathrm{mmol})$ in $\mathrm{CH}_{2} \mathrm{Cl}_{2}(4 \mathrm{~mL})$, was added L-prolinamide $(23 \mathrm{mg}, 0.2 \mathrm{mmol})$ and $\mathrm{N}$ chlorosuccinimide ( $348 \mathrm{mg}, 2.6 \mathrm{mmol})$. The reaction mixture was stirred for 1 hour and then allowed to slowly warm to room temperature over

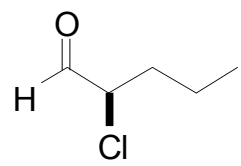
the course of 3 hours at which temperature it was stirred until complete consumption of pentanal (as determined by ${ }^{1} \mathrm{H}$ NMR spectroscopy). After this time, the mixture was diluted with pentanes $(10 \mathrm{~mL})$, cooled $\left(-78{ }^{\circ} \mathrm{C}\right)$, filtered through a fritted funnel, and concentrated on a rotary evaporator in an ice water bath. The resulting oil was dissolved in pentanes $(10 \mathrm{~mL})$, cooled $\left(-78{ }^{\circ} \mathrm{C}\right)$, filtered through a fritted funnel, and concentrated on a rotary evaporator in an ice-water bath to give (2R)-2-chloropentanal (10) $(240 \mathrm{mg}$, $>97 \%$ yield) as a clear oil.

\section{Procedure B:}

To a cold $\left(-30{ }^{\circ} \mathrm{C}\right)$, stirred solution of (5S)-5-benzyl-2,2,3-trimethylimidazolidin-4-one $(10.9 \mathrm{mg}, 0.05 \mathrm{mmol})$ in acetone $(2 \mathrm{~mL})$, was added 2,3,4,5,6,6-hexachloro-2,4cylcohexadien-1-one $(361 \mathrm{mg}, 1.2 \mathrm{mmol})$ and pentanal $(86.1 \mathrm{mg}, 1.0 \mathrm{mmol})$. The reaction mixture stirred at $-30{ }^{\circ} \mathrm{C}$ until the aldehyde was consumed (as determined by ${ }^{1} \mathrm{H}$ NMR spectroscopy). After this time the mixture was filtered through Iatrobeads and eluted with $\mathrm{Et}_{2} \mathrm{O}$ and concentrated on a rotary evaporator in an ice-water bath to provide (2R)-2-chloropentanal (10) (96.5 $\mathrm{mg}, 80 \%$ yield) as a clear oil.

${ }^{1} \mathrm{H}$ NMR (500 MHz, $\left.\mathrm{CDCl}_{3}\right) \delta: 9.44(\mathrm{~d}, 1 \mathrm{H}, J=2.5 \mathrm{~Hz}), 4.14$ (ddd, $1 \mathrm{H}, J=2.5,5.0,7.5$ $\mathrm{Hz}), 1.90(\mathrm{~m}, 1 \mathrm{H}), 1.77(\mathrm{~m}, 1 \mathrm{H}), 1.47(\mathrm{~m}, 2 \mathrm{H}), 0.91(\mathrm{t}, 3 \mathrm{H}, J=7.0 \mathrm{~Hz})$.

${ }^{13} \mathrm{C}$ NMR (125 MHz, $\left.\mathrm{CDCl}_{3}\right) \delta: 195.2,63.6,33.8,18.7,13.2$.

IR (neat): 2963, 2936, 2876, 2849, 1735, 1466, 1434, 1382, 1262, 1206, $1055 \mathrm{~cm}^{-1}$

Exact mass calcd. for $\mathrm{C}_{5} \mathrm{H}_{10} \mathrm{ClO}$ : 121.5868 ; found: 121.5870 .

$[\alpha]_{\mathrm{D}}^{25}: 11.2^{\circ}\left(\mathrm{c}=0.8, \mathrm{CHCl}_{3}\right)$

The enantiomeric excess of $\mathbf{1 0}$ was determined by chiral GC analysis of the primary alcohol derived from the reduction of $\mathbf{1 0}$. Thus, to a solution of $(2 R)$-2-chloropentanal (10) $(12 \mathrm{mg}, 0.1 \mathrm{mmol})$ in $\mathrm{MeOH}(2 \mathrm{~mL})$ was added $\mathrm{NaBH}_{4}(10 \mathrm{mg}, 0.25 \mathrm{mmol})$ and the resulting mixture was stirred at room temperature for 1 hour. The reaction mixture was then quenched with water $(1 \mathrm{~mL})$ and diluted with $\mathrm{Et}_{2} \mathrm{O}(5 \mathrm{~mL})$ and the phases were 
separated. The organic phase was dried $\left(\mathrm{MgSO}_{4}\right)$ and concentrated to afford (2R)-2chloropentanol. Separation of the enantiomers of 2-chloropentanol was accomplished by chiral GC. Temperature program: $70{ }^{\circ} \mathrm{C}$ held for 5 minutes then increased by $20^{\circ} \mathrm{C}$ per minute until $150{ }^{\circ} \mathrm{C}$ and run for 30 minutes. $t_{\mathrm{R}}=21.0$ minutes $((R)$-enantiomer $) ; t_{\mathrm{R}}=21.8$ minutes $((S)$-enantiomer).

\section{Preparation of tetradeca-1,4-divne (23)}

A stirred solution of 1-undecyne $(40.8 \mathrm{mg}, 0.4$ mmol) and ethyl magnesium chloride $(0.26 \mathrm{~mL}$, $0.52 \mathrm{mmol}, 2.0 \mathrm{M}$ solution in $\mathrm{Et}_{2} \mathrm{O}$ ) in THF (4.0

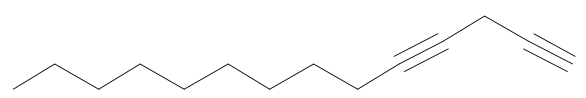

$\mathrm{mL}$ ) was heated at reflux for 2 hours. After this time, the solution was cooled to $0{ }^{\circ} \mathrm{C}$, and copper (I) iodide (7.8 $\mathrm{mg}, 0.04 \mathrm{mmol}$ ) was added. After an additional 30 minutes at $0{ }^{\circ} \mathrm{C}$, propargyl mesylate $(69.6 \mathrm{mg}, 0.52 \mathrm{mmol})$ was added in one portion and the resulting brown solution was stirred at room temperature for 2 hours. After this time the reaction mixture was treated with saturated aqueous $\mathrm{NH}_{4} \mathrm{Cl}(5 \mathrm{~mL})$ and the resulting mixture was diluted with $\mathrm{Et}_{2} \mathrm{O}(20 \mathrm{~mL})$ and the phases were separated. The organic phase was washed with brine $(3 \times 10 \mathrm{~mL})$, dried $\left(\mathrm{MgSO}_{4}\right)$ and concentrated. Purification of the crude product by flash column chromatography ( $30 \mathrm{~g}$ of silica gel, $60: 1$ pentanes - diethyl ether) and removal of trace amounts of solvents (vacuum pump) afforded tetradeca-1,4diyne (23) (70.0 $\mathrm{mg}, 92 \%)$ as a light yellow oil.

${ }^{1} \mathrm{H}$ NMR $\left(500 \mathrm{MHz}, \mathrm{CDCl}_{3}\right) \delta: 3.15(\mathrm{dt}, 2 \mathrm{H}, J=2.5,2.4 \mathrm{~Hz}), 2.15(\mathrm{tt}, 2 \mathrm{H}, J=2.5,7.0$ $\mathrm{Hz}), 2.06$ (t, 1H, $J=2.4 \mathrm{~Hz}$ ), 1.49 (m, 2H), 1.27-1.37 (m, 12H), 0.89 (t, $3 \mathrm{H}, J=7.0 \mathrm{~Hz}$ ).

${ }^{13} \mathrm{C}$ NMR (125 MHz, $\left.\mathrm{CDCl}_{3}\right) \delta: 81.4,79.0,72.9,68.3,31.9,29.5,29.3,29.1,28.9,28.7$, $22.7,18.7,14.1,9.6$.

IR (neat): 3411, 3005, 2925, 2144, 1716, 1420, 1363, 1222, 1093, $902 \mathrm{~cm}^{-1}$

$\operatorname{MS}(\mathrm{CI}, \mathrm{m} / z): 190.3\left(\mathrm{M}^{+}\right)$

\section{Preparation of $(6 Z, 9 Z, 4 S, 5 S)-4,5$-epoxynonadeca-6,9-diene (1)}

To a cold $\left(-78{ }^{\circ} \mathrm{C}\right)$, stirred solution of tetradeca-1,4-diyne (23) $(38 \mathrm{mg}, 0.2$ mmol $)$ and dry THF $(2 \mathrm{~mL})$ was added

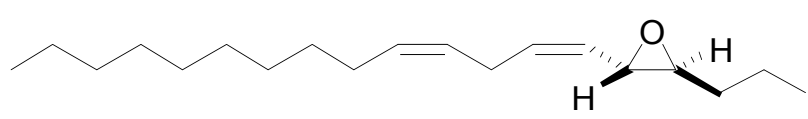
$n$-butyllithium ( $0.1 \mathrm{~mL}, 0.2 \mathrm{mmol}, 2.0 \mathrm{M}$ in hexanes). After 30 seconds, a solution of $(2 R)$-2-chloropentanal (10) $(29 \mathrm{mg}, 0.24 \mathrm{mmol})$ in THF $(0.2 \mathrm{~mL})$ was added and the resulting mixture was stirred for 5 minutes. After this time the light yellow solution was treated with saturated aqueous $\mathrm{NH}_{4} \mathrm{Cl}(5 \mathrm{~mL})$ and diluted with $\mathrm{Et}_{2} \mathrm{O}(20 \mathrm{~mL})$. The phases were separated and the organic phase was washed with brine $(3 \times 10 \mathrm{~mL})$, dried $\left(\mathrm{MgSO}_{4}\right)$ and concentrated to provide the chlorohydrins 25 ( $>20: 1$ mixture of diastereomers as 
determined by ${ }^{1} \mathrm{H}$ NMR spectroscopy) as a crude oil that was used without further purification.

To a cold $\left(0{ }^{\circ} \mathrm{C}\right)$, stirred solution of the crude chlorohydrins $25(0.2 \mathrm{mmol})$ in EtOH $(2.0$ $\mathrm{mL})$ was added Lindlar's catalyst $(4.3 \mathrm{mg}, 0.04 \mathrm{mmol})$ and quinoline $(25.8 \mathrm{mg}, 0.2$ mmol) and the resulting suspension was stirred under an atmosphere of $\mathrm{H}_{2}$ (balloon) for 2 hours at $0{ }^{\circ} \mathrm{C}$. After this time $\mathrm{KOH}(16.8 \mathrm{mg}, 0.3 \mathrm{mmol})$ was added and the suspension was stirred for an additional 30 minutes. The reaction mixture was then filtered through celite and the filtrate was diluted with pentanes $(20 \mathrm{~mL})$, and washed with brine $(3 \times 10$ $\mathrm{mL})$. The combined aqueous phases were extracted with pentanes $(3 \times 10 \mathrm{~mL})$ and the combined organic phases were dried $\left(\mathrm{MgSO}_{4}\right)$ and concentrated. Purification of the crude product by flash column chromatography (45:1 hexanes: ethyl acetate) and removal of trace amounts of solvents (vacuum pump) afforded $(6 Z, 9 Z, 4 S, 5 S)$-4,5-epoxynonadeca6,9-diene (1) (45.7 mg, $82 \%)$ as a clear oil.

The enantiomeric excess of (1) was determined to be $85 \%$ by chiral GC analysis. Temperature program: temperature set at $145{ }^{\circ} \mathrm{C}$ for 80 minutes. $t_{\mathrm{R}}=57.1$ minutes $((S, S)$ enantiomer $) ; t_{\mathrm{R}}=59.0$ minutes $((R, R)$-enantiomer $)$.

${ }^{1} \mathrm{H}$ NMR (500 MHz, $\left.\mathrm{CDCl}_{3}\right) \delta: 5.66(\mathrm{dt}, 1 \mathrm{H}, J=7.0,10.5 \mathrm{~Hz}), 5.33-5.46(\mathrm{~m}, 2 \mathrm{H}), 5.07$ (ddt, $1 \mathrm{H}, J=1.5,9.0,10.5 \mathrm{~Hz}), 3.37(\mathrm{dd}, 1 \mathrm{H}, J=2.0,9.0 \mathrm{~Hz}), 2.96$ (t, 2H, $J=7.0 \mathrm{~Hz}$ ), $2.83(\mathrm{dt}, 1 \mathrm{H}, J=2.5,5.5 \mathrm{~Hz}), 2.06(\mathrm{dt}, 2 \mathrm{H}, J=7.5,7.0 \mathrm{~Hz}), 1.45-1.60(\mathrm{~m}, 4 \mathrm{H}), 1.26-1.37$ $(\mathrm{m}, 14 \mathrm{H}), 0.97$ (t, 3H, $J=7.0 \mathrm{~Hz}), 0.88(\mathrm{t}, 3 \mathrm{H}, J=7.0 \mathrm{~Hz})$.

${ }^{13} \mathrm{C}$ NMR $\left(125 \mathrm{MHz}, \mathrm{CDCl}_{3}\right) \delta: 134.4,131.1,127.2,126.7,60.0,54.3,34.1,31.9,29.60$, $29.59,29.58,29.33,29.32,27.3,26.1,22.7,19.2,14.1,13.9$.

IR (neat): 3010, 2958, 2925, 2854, 1717, $1558 \mathrm{~cm}^{-1}$

Exact mass calcd. for $\mathrm{C}_{19} \mathrm{H}_{33} \mathrm{O}$ : 277.4704; found: 277.4722 .

$[\alpha]_{\mathrm{D}}^{25}:-11.6^{\circ}\left(\mathrm{c}=1.2, \mathrm{CHCl}_{3}\right) ;$ lit. $-12.5\left(\mathrm{c}=4.1, \mathrm{CHCl}_{3}\right)^{4}$

\section{Preparation of (2R)-2-chloroundecanal (12)}

To a cold $\left(0{ }^{\circ} \mathrm{C}\right)$, stirred solution of undecanal $(341 \mathrm{mg}$, $2.0 \mathrm{mmol})$ in dry $\mathrm{CH}_{2} \mathrm{Cl}_{2}(4 \mathrm{~mL})$, was added Lprolinamide (23 $\mathrm{mg}, 0.2 \mathrm{mmol}$ ) and $\mathrm{N}$-chlorosuccinimide (348 $\mathrm{mg}, 2.6 \mathrm{mmol}$ ). The reaction mixture was stirred for

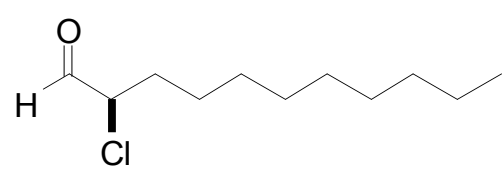
1 hour and then allowed to slowly warm to room temperature over the course of 3 hours at which temperature it was stirred until complete consumption of undecanal (as determined by ${ }^{1} \mathrm{H}$ NMR spectroscopy). After this time, the mixture was diluted with pentanes $(10 \mathrm{~mL})$, cooled $\left(-78^{\circ} \mathrm{C}\right)$, filtered through a fritted funnel, and concentrated on a rotary evaporator in an ice-water bath. The resulting oil was dissolved in pentanes (10 $\mathrm{mL})$, cooled $\left(-78^{\circ} \mathrm{C}\right)$, filtered through a fritted funnel, and concentrated on a rotary 
evaporator in an ice-water bath to give (2R)-2-chloroundecanal (12) (400 mg, 97\% yield) as a clear oil.

${ }^{1} \mathrm{H}$ NMR $\left(500 \mathrm{MHz}, \mathrm{CDCl}_{3}\right) \delta: 9.43(\mathrm{~d}, 1 \mathrm{H}, J=2.5 \mathrm{~Hz}), 4.11$ (ddd, $1 \mathrm{H}, J=2.5,5.5,7.5$ $\mathrm{Hz}), 1.94(\mathrm{~m}, 1 \mathrm{H}), 1.77(\mathrm{~m}, 1 \mathrm{H}), 1.38-1.47(\mathrm{~m}, 2 \mathrm{H}), 1.20-1.30(\mathrm{~m}, 12 \mathrm{H}), 0.91(\mathrm{t}, 3 \mathrm{H}, J=$ $7.0 \mathrm{~Hz})$.

${ }^{13} \mathrm{C}$ NMR (125 MHz, $\left.\mathrm{CDCl}_{3}\right)$ ): 195.1, 63.8, 31.9, 31.7, 29.3, 29.2, 29.1, 28.8, 25.4, 22.6, 14.0.

IR (neat): 3447, 2964, 2936, 2876, 2839, 1735, 1466, 1382, 1262, $1054 \mathrm{~cm}^{-1}$

Exact mass calcd. for $\mathrm{C}_{11} \mathrm{H}_{20} \mathrm{ClO}$ : 203.7322; found: 203.7330 .

$[\alpha]_{\mathrm{D}}^{25}: 14.8^{\circ}(\mathrm{c}=0.6, \mathrm{EtOH})$

\section{Preparation of deca-1,4-divne (24)}

A stirred solution of 1-heptyne $(38.5 \mathrm{mg}, 0.4 \mathrm{mmol})$ and ethyl magnesium chloride $(0.26 \mathrm{~mL}, 0.52 \mathrm{mmol}, 2.0 \mathrm{M}$ solution in $\left.\mathrm{Et}_{2} \mathrm{O}\right)$ in dry THF $(4 \mathrm{~mL})$ was heated at reflux for 2 hours.

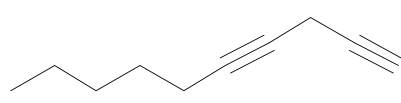

After this time, the solution was cooled to $0{ }^{\circ} \mathrm{C}$, and copper (I) iodide ( $7.8 \mathrm{mg}, 0.04$ mmol) was added. After an additional 30 minutes at $0{ }^{\circ} \mathrm{C}$, propargyl mesylate $(69.6 \mathrm{mg}$, $0.52 \mathrm{mmol}$ ) was added in one portion and the brown solution was stirred at room temperature for 2 hours. After this time the reaction mixture was treated with saturated aqueous $\mathrm{NH}_{4} \mathrm{Cl}(5 \mathrm{~mL})$ and the resulting mixture was diluted with $\mathrm{Et}_{2} \mathrm{O}(20 \mathrm{~mL})$ and the phases were separated. The organic phase was washed with brine $(3 \times 10 \mathrm{~mL})$, dried $\left(\mathrm{MgSO}_{4}\right)$ and concentrated. Purification of the crude product by flash column chromatography ( $30 \mathrm{~g}$ of silica gel, 60:1 pentanes - diethyl ether) and removal of trace amounts of solvents (vacuum pump) afforded deca-1,4-diyne (24) (49 $\mathrm{mg}, 91 \%$ ) as a light yellow oil.

${ }^{1} \mathrm{H}$ NMR (500 MHz, $\left.\mathrm{CDCl}_{3}\right) \delta: 3.14(\mathrm{dt}, 2 \mathrm{H}, J=2.5,2.4 \mathrm{~Hz}), 2.15(\mathrm{tt}, 2 \mathrm{H}, J=2.5,7.0$ $\mathrm{Hz}), 2.05(\mathrm{t}, 1 \mathrm{H}, J=2.4 \mathrm{~Hz}), 1.49(\mathrm{tt}, 2 \mathrm{H}, J=7.0,7.0 \mathrm{~Hz}), 1.20-1.35(\mathrm{~m}, 4 \mathrm{H}), 0.89$ (t, $3 \mathrm{H}, J=7.0 \mathrm{~Hz})$.

${ }^{13} \mathrm{C}$ NMR (125 MHz, $\left.\mathrm{CDCl}_{3}\right)$ ): 81.3, 79.0, 72.9, 68.3, 31.0, 28.3, 22.2, 18.6, 14.0, 9.6.

IR (neat): 3015, 2921, 2854, 2214, 1713, $1467 \mathrm{~cm}^{-1}$

MS (CI, $m / z): 134.2\left(\mathrm{M}^{+}\right)$ 


\section{Preparation of $(6 Z, 9 Z, 11 S, 12 S)-11,12$-epoxvhenicosa-6,9-diene (2)}

To a cold $\left(-78{ }^{\circ} \mathrm{C}\right)$, stirred solution of deca-1,4-diyne (24) (26.8 $\mathrm{mg}, 0.2 \mathrm{mmol})$ in dry THF

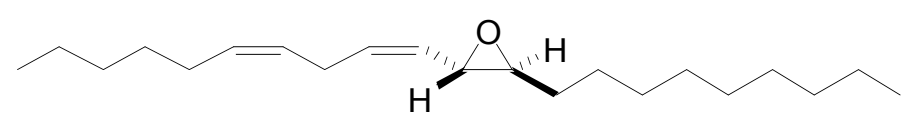

$(2 \mathrm{~mL})$ was added $n$-butyllithium $(0.1 \mathrm{~mL}, 0.2 \mathrm{mmol}, 2.0 \mathrm{M}$ in hexanes). After 30 seconds, a solution of (2R)-2-chloroundecanal (12) $(49 \mathrm{mg}, 0.24 \mathrm{mmol})$ in THF $(0.2 \mathrm{~mL})$ was added and the resulting mixture was stirred for 5 minutes. After this time the light yellow solution was treated with saturated aqueous $\mathrm{NH}_{4} \mathrm{Cl}(5 \mathrm{~mL})$ and diluted with $\mathrm{Et}_{2} \mathrm{O}$ $(20 \mathrm{~mL})$. The phases were separated and the organic phase was washed with brine $(3 \times 10$ $\mathrm{mL}$ ), dried $\left(\mathrm{MgSO}_{4}\right)$ and concentrated to provide the chlorohydrins 26 ( $>20: 1$ mixture of diastereomers as determined by ${ }^{1} \mathrm{H}$ NMR spectroscopy) as a crude oil that was used without further purification.

To a cold $\left(0{ }^{\circ} \mathrm{C}\right)$, stirred solution of the crude chlorohydrins $\mathbf{2 6}(0.2 \mathrm{mmol})$ in EtOH (2.0 $\mathrm{mL}$ ) was added Lindlar's catalyst $(4.3 \mathrm{mg}, 0.04 \mathrm{mmol})$ and quinoline $(25.8 \mathrm{mg}, 0.2$ $\mathrm{mmol}$ ) and the resulting suspension was stirred under an atmosphere of $\mathrm{H}_{2}$ (balloon) for 2 hours at $0{ }^{\circ} \mathrm{C}$. After this time $\mathrm{KOH}(16.8 \mathrm{mg}, 0.3 \mathrm{mmol})$ was added and the suspension was stirred for a further 30 minutes at $0{ }^{\circ} \mathrm{C}$. The reaction mixture was then filtered through celite and the filtrate was diluted with pentanes $(20 \mathrm{~mL})$ and washed with brine $(3 \times 10 \mathrm{~mL})$. The combined aqueous phases were extracted with pentanes $(3 \times 10 \mathrm{~mL})$ and the combined organic phases were dried $\left(\mathrm{MgSO}_{4}\right)$ and concentrated. Purification of the crude product by flash column chromatography (45:1 hexanes: ethyl acetate) and removal of trace amounts of solvents (vacuum pump) afforded $(6 Z, 9 Z, 11 S, 12 S)-11,12$ epoxyhenicosa-6,9-diene (2) $(51.5 \mathrm{mg}, 84 \%)$ as a clear oil.

${ }^{1} \mathrm{H}$ NMR $\left(500 \mathrm{MHz}, \mathrm{CDCl}_{3}\right) \delta: 5.66(\mathrm{dt}, 1 \mathrm{H}, J=7.0,10.5 \mathrm{~Hz}), 5.33-5.47(\mathrm{~m}, 2 \mathrm{H}), 5.06$ (ddt, $1 \mathrm{H}, J=1.5,9.0,10.5 \mathrm{~Hz}), 3.37$ (dd, $1 \mathrm{H}, J=2.0,9.0 \mathrm{~Hz}), 2.96(\mathrm{t}, 2 \mathrm{H}, J=7.0 \mathrm{~Hz}$ ), $2.82(\mathrm{dt}, 1 \mathrm{H}, J=2.0,6.0 \mathrm{~Hz}), 2.06(\mathrm{dt}, 2 \mathrm{H}, J=7.5,7.0 \mathrm{~Hz}), 1.58(\mathrm{~m}, 2 \mathrm{H}), 1.45(\mathrm{~m}, 2 \mathrm{H})$, $1.26-1.38$ (m, 18H), 0.89 (t, 3H, $J=7.0 \mathrm{~Hz}), 0.88(\mathrm{t}, 3 \mathrm{H}, J=7.0 \mathrm{~Hz})$.

${ }^{13} \mathrm{C}$ NMR $\left(125 \mathrm{MHz}, \mathrm{CDCl}_{3}\right) \delta: 134.3,131.1,127.3,126.7,60.2,54.3,32.1,31.9,31.5$, $29.55,29.52,29.45,29.30,29.24,27.2,26.1,25.9,22.7,22.6,14.11,14.07$.

IR (neat): 3004, 2925, 2855, 1721, $1636 \mathrm{~cm}^{-1}$

Exact mass calcd. for $\mathrm{C}_{21} \mathrm{H}_{39} \mathrm{O}: 307.5401$; found: 307.5421 .

$[\alpha]_{\mathrm{D}}^{25}:-9.6^{\circ}\left(\mathrm{c}=1.0, \mathrm{CHCl}_{3}\right) ;$ lit. $-10.8\left(\mathrm{c}=1.08, \mathrm{CHCl}_{3}\right)^{5}$

\section{Preparation of $(4 S, 5 S)-4,5$-epoxydodec-6-yne (19a)}

To a cold $\left(-78{ }^{\circ} \mathrm{C}\right)$, stirred solution of 1-heptyne (48.1 $\mathrm{mg}, 0.5 \mathrm{mmol})$ in dry THF $(2.5 \mathrm{~mL})$ was added $n$ butyllithium $(0.25 \mathrm{~mL}, 0.5 \mathrm{mmol}, 2.0 \mathrm{M}$ in hexanes).

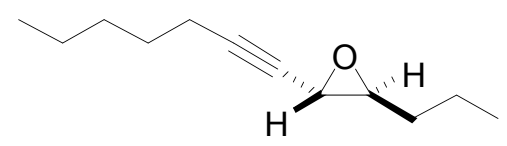
After the mixture had stirred for 10 minutes, a solution of $(2 R)$-2-chloropentanal (10) 
(66.3 $\mathrm{mg}, 0.55 \mathrm{mmol})$ in THF $(0.25 \mathrm{~mL})$ was added and the reaction mixture was stirred for an additional 10 minutes. After this time, the clear solution was treated with saturated aqueous $\mathrm{NH}_{4} \mathrm{Cl}(5 \mathrm{~mL})$ and diluted with $\mathrm{Et}_{2} \mathrm{O}(20 \mathrm{~mL})$. The phases were separated and the organic phase was washed with brine $(3 \times 10 \mathrm{~mL})$, dried $\left(\mathrm{MgSO}_{4}\right)$ and concentrated to provide the chlorohydrins 18a $\left(>20: 1\right.$ mixture of diastereomers as determined by ${ }^{1} \mathrm{H}$ NMR spectroscopy) as a crude oil that was used without further purification.

To a stirred solution of the crude chlorohydrins 18a $(0.5 \mathrm{mmol})$ in EtOH $(2.5 \mathrm{~mL})$ at room temperature was added $\mathrm{KOH}(84 \mathrm{mg}, 1.5 \mathrm{mmol})$. After the mixture had been stirred for 30 minutes the resulting yellow solution was diluted with pentanes $(20 \mathrm{~mL})$ and washed with brine $(3 \times 10 \mathrm{~mL})$. The aqueous phase was extracted with pentanes $(3 \times 10$ $\mathrm{mL})$ and the combined organic phases were dried $\left(\mathrm{MgSO}_{4}\right)$ and concentrated. Purification of the crude product by flash column chromatography (30:1 hexanes: ethyl acetate) and removal of trace amounts of solvents (vacuum pump) afforded (4S,5S)-4,5-epoxydodec6-yne (19a) $(75.2 \mathrm{mg}, 86 \%)$ as a light yellow oil.

The enantiomeric excess of 19a was determined to be $85 \%$ by chiral GC analysis. Temperature program: temperature set at $100{ }^{\circ} \mathrm{C}$ for 30 minutes. $t_{\mathrm{R}}=10.7$ minutes $((S, S)$ enantiomer $) ; t_{\mathrm{R}}=11.4$ minutes $((R, R)$-enantiomer $)$.

${ }^{1} \mathrm{H}$ NMR $\left(500 \mathrm{MHz}, \mathrm{CDCl}_{3}\right) \delta: 3.08(\mathrm{dt}, 1 \mathrm{H}, J=2.0,1.5 \mathrm{~Hz}), 3.02(\mathrm{dt}, 1 \mathrm{H}, J=2.0,5.0$ $\mathrm{Hz}), 2.19$ (dt, $2 \mathrm{H}, J=1.5,6.0 \mathrm{~Hz}), 1.44-1.54(\mathrm{~m}, 6 \mathrm{H}), 1.26-1.38(\mathrm{~m}, 4 \mathrm{H}), 0.96(\mathrm{t}, 3 \mathrm{H}, J=$ $7.0 \mathrm{~Hz}), 0.89$ (t, 3H, $J=7 \mathrm{~Hz})$.

${ }^{13} \mathrm{C}$ NMR (125 MHz, $\left.\mathrm{CDCl}_{3}\right)$ ): 84.9, 77.0, 60.6, 45.9, 34.0, 31.2, 38.3, 23.4, 19.2, 18.9, $14.1,14.1$.

IR (neat): 2959, 2934, 2867, 2238, 1460, 1233, 1154, 898, $862 \mathrm{~cm}^{-1}$

Exact mass calcd. for $\mathrm{C}_{12} \mathrm{H}_{21} \mathrm{O}$ : 181.2981; found: 181.2992.

$[\alpha]_{\mathrm{D}}^{25}:-3^{\circ}\left(\mathrm{c}=0.8, \mathrm{CHCl}_{3}\right)$

\section{Preparation of $(6 E, 4 S, 5 S)-4,5$-epoxyhexadec-6-ene $(19 \mathrm{~b})$}

To a cold $\left(-78^{\circ} \mathrm{C}\right)$, stirred solution of $(E)-1-$ iodoundec-1-ene $(28.0 \mathrm{mg}, 0.1 \mathrm{mmol})^{6}$ in dry THF $(1.0 \mathrm{~mL})$ was added $n$-butyllithium $(0.05$

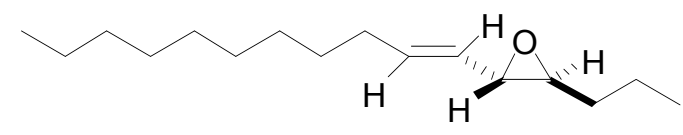
$\mathrm{mL}, 0.1 \mathrm{mmol}, 2.0 \mathrm{M}$ in hexanes). After 10 minutes, a solution of (2R)-2-chloropentanal (10) $(13.3 \mathrm{mg}, 0.11 \mathrm{mmol})$ in THF $(0.1 \mathrm{~mL})$ was added and the reaction mixture was stirred for an additional 10 minutes. After this time, the clear solution was treated with saturated aqueous $\mathrm{NH}_{4} \mathrm{Cl}(5 \mathrm{~mL})$ and diluted with $\mathrm{Et}_{2} \mathrm{O}(20 \mathrm{~mL})$. The phases were separated and the organic phase was washed with brine $(3 \times 10 \mathrm{~mL})$, dried $\left(\mathrm{MgSO}_{4}\right)$ and concentrated to provide the chlorohydrins $\mathbf{1 8 b}$ (17:1 mixture of diastereomers as determined by ${ }^{1} \mathrm{H}$ NMR spectroscopy) as a crude oil which was used without further purification. 
To a stirred solution of the crude chlorohydrins $\mathbf{1 8 b}(0.1 \mathrm{mmol})$ in EtOH $(1.0 \mathrm{~mL})$ at room temperature was added $\mathrm{KOH}(17 \mathrm{mg}, 0.3 \mathrm{mmol})$. After 30 minutes the resulting yellow solution was diluted with pentanes $(20 \mathrm{~mL})$ and washed with brine $(3 \times 10 \mathrm{~mL})$. The combined aqueous phases were extracted with pentanes $(3 \times 10 \mathrm{~mL})$ and the combined organic phases were dried $\left(\mathrm{MgSO}_{4}\right)$ and concentrated. Purification of the crude product by flash column chromatography (30:1 hexanes: ethyl acetate) and removal of trace amounts of solvents (vacuum pump) afforded $(6 E, 4 S, 5 S)$-4,5-epoxyhexadec-6-ene (19b) (18 $\mathrm{mg}, 75 \%)$ as a yellow oil.

${ }^{1} \mathrm{H}$ NMR (600 MHz, $\left.\mathrm{CDCl}_{3}\right) \delta: 5.90(\mathrm{dt}, 1 \mathrm{H}, J=7.2,15.6 \mathrm{~Hz}), 5.15(\mathrm{dd}, 1 \mathrm{H}, J=8.4,15.6$ $\mathrm{Hz}), 3.07$ (dd, $1 \mathrm{H}, J=7.8,8.4 \mathrm{~Hz}), 2.82(\mathrm{~m}, 1 \mathrm{H}), 2.05(\mathrm{dt}, 2 \mathrm{H}, J=7.2,7.0 \mathrm{~Hz}), 1.53(\mathrm{~m}$, $6 \mathrm{H}), 1.37$ (m, 2H), 1.26-1.30 (m, 10H), 0.95 (t, $3 \mathrm{H}, J=7.2 \mathrm{~Hz}), 0.88$ (t, $3 \mathrm{H}, J=7.2 \mathrm{~Hz})$.

${ }^{13} \mathrm{C}$ NMR $\left(150 \mathrm{MHz}, \mathrm{CDCl}_{3}\right) \delta: 136.8,127.4,60.2,58.8,34.1,32.4,31.9,29.5,29.5$, 29.3, 29.1, 28.9, 22.7, 19.2, 14.1, 14.0.

IR (neat): 2964, 2926, 2855, 1713, 1455, 1378, 965, $902 \mathrm{~cm}^{-1}$

Exact mass calcd. for $\mathrm{C}_{16} \mathrm{H}_{30} \mathrm{O}$ : 238.4084; found: 238.4076 .

$[\alpha]_{\mathrm{D}}^{25}:-7.9^{\circ}\left(\mathrm{c}=1.4, \mathrm{CHCl}_{3}\right)$

\section{Preparation of $(6 E, 4 S, 5 S)-4,5$-epoxydodec-6-ene (19c)}

To a cold $\left(-78^{\circ} \mathrm{C}\right)$, stirred solution of $(E)$-1-iodohept-1ene $(112 \mathrm{mg}, 0.5 \mathrm{mmol})^{7}$ in dry THF $(5.0 \mathrm{~mL})$ was added $n$-butyllithium $(0.25 \mathrm{~mL}, 0.5 \mathrm{mmol}, 2.0 \mathrm{M}$ in hexanes).

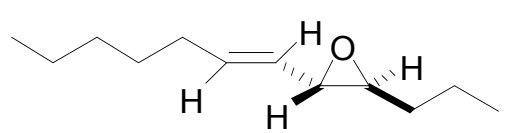
After 10 minutes, a solution of (2R)-2-chloropentanal (10) $(66.3 \mathrm{mg}, 0.55 \mathrm{mmol})$ in THF $(0.5 \mathrm{~mL})$ was added and the reaction mixture was stirred for an additional 10 minutes. After this time, the clear solution was treated with saturated aqueous $\mathrm{NH}_{4} \mathrm{Cl}(5 \mathrm{~mL})$ and diluted with $\mathrm{Et}_{2} \mathrm{O}(20 \mathrm{~mL})$. The phases were separated and the organic phase was washed with brine $(3 \times 10 \mathrm{~mL})$, dried $\left(\mathrm{MgSO}_{4}\right)$ and concentrated to provide the chlorohydrins $\mathbf{1 8 c}$ (13:1 mixture of diastereomers as determined by ${ }^{1} \mathrm{H}$ NMR spectroscopy) as a crude oil which was used without further purification.

To a stirred solution of the crude chlorohydrins $18 \mathrm{c}(0.5 \mathrm{mmol})$ in EtOH $(5.0 \mathrm{~mL})$ at room temperature was added $\mathrm{KOH}(85 \mathrm{mg}, 1.5 \mathrm{mmol})$. After 30 minutes the resulting yellow solution was diluted with pentanes $(20 \mathrm{~mL})$ and washed with brine $(3 \times 10 \mathrm{~mL})$. The combined aqueous phases were extracted with pentanes $(3 \times 10 \mathrm{~mL})$ and the combined organic phases were dried $\left(\mathrm{MgSO}_{4}\right)$ and concentrated. Purification of the crude product by flash column chromatography (30:1 hexanes: ethyl acetate) and removal of trace amounts of solvents (vacuum pump) afforded (6E,4S,5S)-4,5-epoxydodec-6-ene (19c) $(79 \mathrm{mg}, 87 \%)$ as a yellow oil. 
${ }^{1} \mathrm{H}$ NMR $\left(500 \mathrm{MHz}, \mathrm{CDCl}_{3}\right) \delta: 5.88(\mathrm{dt}, 1 \mathrm{H}, J=7.0,15.5 \mathrm{~Hz}), 5.15(\mathrm{dd}, 1 \mathrm{H}, J=9.0,15.5$ $\mathrm{Hz}), 3.04(\mathrm{~m}, 1 \mathrm{H}), 2.80(\mathrm{~m}, 1 \mathrm{H}), 2.04(\mathrm{dt}, 2 \mathrm{H}, J=7.0,7.0 \mathrm{~Hz}), 1.24-1.55(\mathrm{~m}, 10 \mathrm{H}), 0.95$ (t, $3 \mathrm{H}, J=7.0 \mathrm{~Hz}), 0.87$ (t, $3 \mathrm{H}, J=7.5 \mathrm{~Hz})$.

${ }^{13} \mathrm{C}$ NMR $\left(125 \mathrm{MHz}, \mathrm{CDCl}_{3}\right) \delta: 136.6,127.4,60.2,58.8,34.0,32.3,31.3,28.6,22.5$, 19.2, 14.0, 13.9.

IR (neat): 2950, 2922, 2860, 1710, 1440, 1322, $922 \mathrm{~cm}^{-1}$

Exact mass calcd. for $\mathrm{C}_{12} \mathrm{H}_{23} \mathrm{O}$ : 183.3140 ; found: 183.3152 .

$[\alpha]_{\mathrm{D}}^{25}:-4.5^{\circ}\left(\mathrm{c}=0.6, \mathrm{CHCl}_{3}\right)$

Determination of optical purity: to a stirred solution solution of $(6 E, 4 S, 5 S)-4,5$ epoxydodec-6-ene (19c) $(5 \mathrm{mg})$ in $\mathrm{EtOH}$ was added $\mathrm{Pd} / \mathrm{C}(0.1 \mathrm{~mol} \%)$ and the resulting suspension was stirred under an atmosphere of $\mathrm{H}_{2}$ (balloon) for 3 hours. After this time, the reaction mixture was filtered through celite and concentrated and the crude oil was purified by flash chromatography (30:1 hexanes: ethyl acetate) to provide $(4 S, 5 S)-4,5-$ epoxydodecane. The observed specific rotation of this material $\left([\alpha]_{\mathrm{D}}{ }^{25}:-24.9\right)$ was consistent with that of a sample of $(4 S, 5 S)$-4,5-epoxydodecane that was produced from $(6 Z, 4 S, 5 S)-4,5$-epoxydodec-6-ene (19d) (85\% ee as determined by chiral GC, see below) in the same manner $\left([\alpha]_{\mathrm{D}}^{25}:-24.7\right)$.

\section{Preparation of $(6 Z, 4 S, 5 S)-4,5$-epoxydodec-6-ene (19d)}

\section{Procedure A:}

To a cold $\left(0{ }^{\circ} \mathrm{C}\right)$, stirred solution of $(4 S, 5 S)-4,5$ epoxydodec-6-yne (19a) $(90.1 \mathrm{mg}, 0.5 \mathrm{mmol})$ in $\mathrm{EtOH}$ $(2.5 \mathrm{~mL})$ was added Lindlar's catalyst $(5.3 \mathrm{mg}, 0.05$

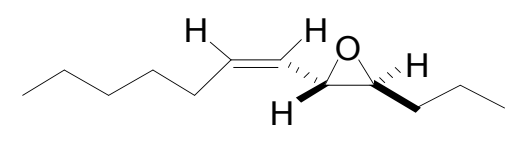
$\mathrm{mmol})$ and quinoline $(6.5 \mathrm{mg}, 0.05 \mathrm{mmol})$ and the resulting suspension was stirred under an atmosphere of $\mathrm{H}_{2}$ (balloon) for 30 minutes at $0{ }^{\circ} \mathrm{C}$. The reaction mixture was then filtered through celite and the filtrate was diluted with $\mathrm{Et}_{2} \mathrm{O}(20 \mathrm{~mL})$ and washed with brine $(3 \times 10 \mathrm{~mL})$. The combined aqueous phases were extracted with $\mathrm{Et}_{2} \mathrm{O}(3 \times 10 \mathrm{~mL})$ and the combined organic phases were dried $\left(\mathrm{MgSO}_{4}\right)$ and concentrated. Purification of the crude product by flash column chromatography (30:1 hexanes: ethyl acetate) and removal of trace amounts of solvents (vacuum pump) afforded (6Z,4S,5S)-4,5epoxydodec-6-ene (19d) $(85.7 \mathrm{mg}, 94 \%)$ as a light yellow oil.

\section{Procedure B:}

To a cold $\left(-78{ }^{\circ} \mathrm{C}\right)$, stirred solution of $(Z)-1$-iodohept-1-ene $(112 \mathrm{mg}, 0.5 \mathrm{mmol})^{8}$ in dry THF $(5.0 \mathrm{~mL})$ was added $n$-butyllithium $(0.25 \mathrm{~mL}, 0.5 \mathrm{mmol}, 2.0 \mathrm{M}$ in hexanes). After 10 minutes, a solution of (2R)-2-chloropentanal (10) $(66.3 \mathrm{mg}, 0.55 \mathrm{mmol})$ in THF $(0.5$ $\mathrm{mL}$ ) was added and the reaction mixture was stirred for an additional 10 minutes. After this time, the clear solution was treated with saturated aqueous $\mathrm{NH}_{4} \mathrm{Cl}(5 \mathrm{~mL})$ and diluted 
with $\mathrm{Et}_{2} \mathrm{O}(20 \mathrm{~mL})$. The phases were separated and the organic phase was washed with brine $(3 \times 10 \mathrm{~mL})$, dried $\left(\mathrm{MgSO}_{4}\right)$ and concentrated to provide the chlorohydrins $\mathbf{1 8 d}$ (14:1 mixture of diastereomers as determined by ${ }^{1} \mathrm{H}$ NMR spectroscopy) as a crude oil which was used without further purification.

To a stirred solution of the crude chlorohydrins $\mathbf{1 8 d}(0.5 \mathrm{mmol})$ in EtOH $(5.0 \mathrm{~mL})$ at room temperature was added $\mathrm{KOH}(85 \mathrm{mg}, 1.5 \mathrm{mmol})$. After 30 minutes the resulting yellow solution was diluted with pentanes $(20 \mathrm{~mL})$ and washed with brine $(3 \times 10 \mathrm{~mL})$. The combined aqueous phases were extracted with pentanes $(3 \times 10 \mathrm{~mL})$ and the combined organic phases were dried $\left(\mathrm{MgSO}_{4}\right)$ and concentrated. Purification of the crude product by flash column chromatography (30:1 hexanes: ethyl acetate) and removal of trace amounts of solvents (vacuum pump) afforded $(6 Z, 4 S, 5 S)$-4,5-epoxyhexadec-6-ene (19d) $(70 \mathrm{mg}, 77 \%)$ as a yellow oil.

The enantiomeric excess of the epoxide 19d derived from both procedures A and B was determined by chiral GC analysis to be $85 \%$. Temperature program: temperature held at $70{ }^{\circ} \mathrm{C}$ for 50 minutes. $t_{\mathrm{R}}=35.3$ minutes $((S, S)$-enantiomer $) ; t_{\mathrm{R}}=36.4$ minutes $((R, R)$ enantiomer).

${ }^{1} \mathrm{H}$ NMR (500 MHz, $\left.\mathrm{CDCl}_{3}\right) \delta: 5.68(\mathrm{dt}, 1 \mathrm{H}, J=7.5,11.0 \mathrm{~Hz}), 5.03(\mathrm{ddt}, 1 \mathrm{H}, J=1.5,9.0$, $11.0 \mathrm{~Hz}), 3.35(\mathrm{dd}, 1 \mathrm{H}, J=2.5,9.0 \mathrm{~Hz}), 2.81(\mathrm{dt}, 1 \mathrm{H}, J=2.0,5.0 \mathrm{~Hz}), 2.20(\mathrm{~m}, 2 \mathrm{H}), 1.54-$ $1.40(\mathrm{~m}, 6 \mathrm{H}), 1.30(\mathrm{~m}, 4 \mathrm{H}), 0.96(\mathrm{t}, 3 \mathrm{H}, J=7.5 \mathrm{~Hz}), 0.89$ (t, 3H, $J=7.5 \mathrm{~Hz})$.

${ }^{13} \mathrm{C}$ NMR $\left(125 \mathrm{MHz}, \mathrm{CDCl}_{3}\right) \delta: 136.5,127.0,60.0,54.4,34.1,31.3,29.2,27.6,22.5$, $19.2,14.0,13.9$.

IR (neat): 3205, 2960, 2931, 2858, 1636, 1466, 1380, $901 \mathrm{~cm}^{-1}$

Exact mass calcd. for $\mathrm{C}_{12} \mathrm{H}_{23} \mathrm{O}$ : 183.3140; found: 183.3152 .

$[\alpha]_{\mathrm{D}}^{25}:-9.7^{\circ}\left(\mathrm{c}=1.4, \mathrm{CHCl}_{3}\right)$

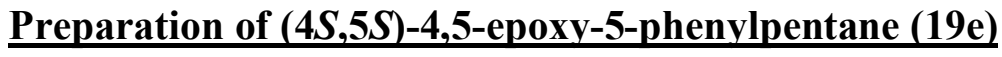

To a cold $\left(-78{ }^{\circ} \mathrm{C}\right)$, stirred solution of bromobenzene $(78.51 \mathrm{mg}$, $0.5 \mathrm{mmol})$ in dry THF $(2.5 \mathrm{~mL})$ under argon was added $n$ butyllithium $(0.25 \mathrm{~mL}, 0.5 \mathrm{mmol}, 2.0 \mathrm{M}$ in hexanes $)$. After 10 minutes a solution of $(2 R)$-2-chloropentanal (10) $(66.3 \mathrm{mg}, 0.55$

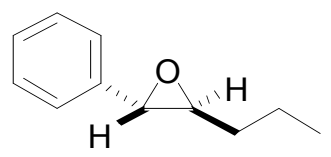
mmol) in THF $(0.25 \mathrm{~mL})$ was added and the reaction mixture was stirred for an additional 10 minutes. After this time, the clear solution was treated with saturated aqueous $\mathrm{NH}_{4} \mathrm{Cl}(5 \mathrm{~mL})$ and diluted with $\mathrm{Et}_{2} \mathrm{O}(20 \mathrm{~mL})$. The phases were separated and the organic phase was washed with brine $(3 \times 10 \mathrm{~mL})$, dried $\left(\mathrm{MgSO}_{4}\right)$ and concentrated to provide the chlorohydrins 18e (13:1 mixture of diastereomers as determined by ${ }^{1} \mathrm{H}$ NMR spectroscopy) as a crude oil which was used without further purification. 
To a stirred solution of the crude chlorohydrins $18 \mathrm{e}(0.5 \mathrm{mmol})$ in EtOH $(2.5 \mathrm{~mL})$ at room temperature was added $\mathrm{KOH}(84 \mathrm{mg}, 1.5 \mathrm{mmol})$. After 30 minutes the resulting yellow solution was diluted with pentanes $(20 \mathrm{~mL})$ and washed with brine $(3 \times 10 \mathrm{~mL})$. The combined aqueous phases were extracted with pentanes $(3 \times 10 \mathrm{~mL})$ and the combined organic phases were dried $\left(\mathrm{MgSO}_{4}\right)$ and concentrated. Purification of the crude product by flash column chromatography (30:1 hexanes: ethyl acetate) and removal of trace amounts of solvents (vacuum pump) afforded (4S,5S)-4,5-epoxy-5-phenylpentane (19e) $(68.4 \mathrm{mg}, 84 \%$, d.r. $=14: 1)$ as a light yellow oil.

${ }^{1} \mathrm{H}$ NMR (500 MHz, $\left.\mathrm{CDCl}_{3}\right)$ 8: 7.36-7.27 (m, 5H), $3.61(\mathrm{~d}, 1 \mathrm{H}, J=2.0 \mathrm{~Hz}), 2.95(\mathrm{dt}, 1 \mathrm{H}$, $J=2.0,5.5 \mathrm{~Hz}), 1.64-1.70(\mathrm{~m}, 2 \mathrm{H}), 1.52-1.58(\mathrm{~m}, 2 \mathrm{H}), 1.00$ (t, $3 \mathrm{H}, J=7.5 \mathrm{~Hz})$.

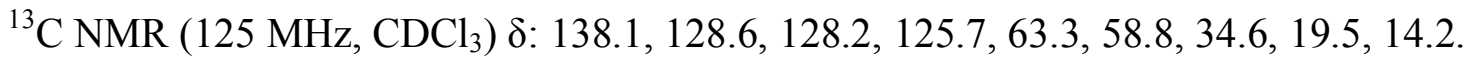

IR (neat): 3080, 3062, 3026, 2961, 2933, 2873, 1605, 1498, 1461, 1380, 1203, $870 \mathrm{~cm}^{-1}$

Exact mass calcd. for $\mathrm{C}_{11} \mathrm{H}_{14} \mathrm{O}: 162.2278$; found: 162.2284 .

$[\alpha]_{\mathrm{D}}^{25}:-31.5^{\circ}\left(\mathrm{c}=0.8, \mathrm{CHCl}_{3}\right)$

The enantiomeric excess of 19e was determined by transformation to (2S)-1phenylpentan-2-ol. Thus, a solution of (4S,5S)-4,5-epoxy-5-phenylpentane (19e) (16 mg, $0.1 \mathrm{mmol})$ and $\mathrm{NaBH}_{4}(10 \mathrm{mg}, 0.25 \mathrm{mmol})$ in $\mathrm{MeOH}(2 \mathrm{~mL})$ was stirred at room temperature for 1 hour. The reaction mixture was then treated with water $(1 \mathrm{~mL})$, diluted with $\mathrm{Et}_{2} \mathrm{O}(5 \mathrm{~mL})$, and the phases were separated. The organic phase was dried $\left(\mathrm{MgSO}_{4}\right)$ and concentrated. Purification of the crude product by flash column chromatography (10:1 hexanes: ethyl acetate) and removal of trace amounts of solvents (vacuum pump) afforded $(2 S)$-1-phenylpentan-2-ol. $[\alpha]_{\mathrm{D}}^{20}=3.7^{\circ}$ (obs.) $(\mathrm{c}=1.1$, EtOH $)$; lit. $4.2^{\circ}(\mathrm{c}=1.8$, $\mathrm{EtOH}){ }^{9}$

\section{Preparation of $(4 S, 5 S)-4,5$-epoxyundecane (19f)}

To a cold $\left(-78^{\circ} \mathrm{C}\right)$, stirred solution of $n$-hexyllithium $(0.25$ $\mathrm{mL}, 0.5 \mathrm{mmol}, 2.0 \mathrm{M}$ in hexanes) in dry THF $(2.5 \mathrm{~mL})$ was added a solution of (2R)-2-chloropentanal (10) $(66.3$

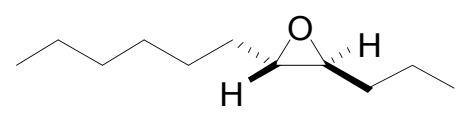
$\mathrm{mg}, 0.55 \mathrm{mmol})$ in THF $(0.25 \mathrm{~mL})$ and the reaction mixture was stirred for 10 minutes. After this time the clear solution was treated with saturated aqueous $\mathrm{NH}_{4} \mathrm{Cl}(5 \mathrm{~mL})$ and diluted with $\mathrm{Et}_{2} \mathrm{O}(20 \mathrm{~mL})$. The phases were separated and the organic phase was washed with brine $(3 \times 10 \mathrm{~mL})$, dried $\left(\mathrm{MgSO}_{4}\right)$ and concentrated to provide the chlorohydrins $\mathbf{1 8 f}$ (8:1 mixture of diastereomers as determined by ${ }^{1} \mathrm{H}$ NMR spectroscopy) as a crude oil which was used without further purification.

To a stirred solution of the crude chlorohydrins $\mathbf{1 8 f}(0.5 \mathrm{mmol})$ in EtOH $(2.5 \mathrm{~mL})$ at room temperature was added $\mathrm{KOH}(84 \mathrm{mg}, 1.5 \mathrm{mmol})$. After the mixture had been stirred for 30 minutes the resulting yellow solution was diluted with pentanes $(20 \mathrm{~mL})$ and washed with brine $(3 \times 10 \mathrm{~mL})$. The combined aqueous phases were extracted with pentanes $(3 \mathrm{x}$ 
$10 \mathrm{~mL})$ and the combined organic phases were dried $\left(\mathrm{MgSO}_{4}\right)$ and concentrated. Purification of the crude product by flash column chromatography (30:1 hexanes: ethyl acetate) and removal of trace amounts of solvents (vacuum pump) afforded (4S,5S)-4,5epoxyundecane (19f) $(67.3 \mathrm{mg}, 79 \%$, d.r.= 8:1) as a light yellow oil.

${ }^{1} \mathrm{H}$ NMR $\left(500 \mathrm{MHz}, \mathrm{CDCl}_{3}\right) \delta: 2.66(\mathrm{~m}, 2 \mathrm{H}), 1.50(\mathrm{~m}, 8 \mathrm{H}), 1.29(\mathrm{~m}, 6 \mathrm{H}), 0.95(\mathrm{t}, 3 \mathrm{H}, J=$ $7.0 \mathrm{~Hz}), 0.88$ (t, 3H, $J=7.0 \mathrm{~Hz})$.

${ }^{13} \mathrm{C}$ NMR $\left(125 \mathrm{MHz}, \mathrm{CDCl}_{3}\right) \delta: 58.9,58.8,34.4,32.3,31.9,29.3,26.2,22.7,19.5,14.2$, 14.1.

IR (neat): 2960, 2928, 2861, 1733, 1465, 1156, 1094, $904 \mathrm{~cm}^{-1}$

Exact mass calcd. for $\mathrm{C}_{11} \mathrm{H}_{22} \mathrm{O}: 170.2951$; found: 170.2962 .

$[\alpha]_{\mathrm{D}}^{25}:-26.5^{\circ}\left(\mathrm{c}=0.6, \mathrm{CHCl}_{3}\right)$

\section{$\underline{\text { References }}$}

1. Still, W. C.; Kahn, M.; Mitra, A. J. Org. Chem., 1978, 43, 2923.

2. Konig, W. A.; Gehrke, B.; Icheln, D.; Evers, P.; Donnecke, J.; Wang, W. J. High Resol. Chromatography, 1992, 15, 367.

3. Pietruska, J.; Hochmuth, D. H.; Gehrke, B.; Icheln, D.; Runge, T.; Konig, W. Tetrahedron: Asymmetry, 1992, 3, 661.

4. Francke, W. German Patent 19814330.3, 1998.

5. Muto, S.; Mori, K. Eur. J. Org. Chem. 2001, 4635.

6. (E)-1-iodoundec-1-ene was synthesized according to the procedure described in: Tius, M. A.; Busch-Petersen, J.; Yamashita, M. Tetrahedron Lett. 1998, 52, 930.

7. (E)-1-iodohept-1-ene was synthesized according to the procedure described in: Brown, C. B.; Hamaoka, T.; Ravindran, N. J. Am. Chem. Soc. 1973, 95, 5786.

8. (Z)-1-iodohept-1-ene was synthesized according to the procedure described in: Miller, R. B.; McGarvey, G. J. Org. Chem. 1978, 43, 4424.

9. Ruano, J. L. G.; Fernandez-Ibanez, M. A.; Maestro, M. C.; Rodriguez-Fernandez, M. M. J. Org. Chem. 2005, 70, 1796-1801. 


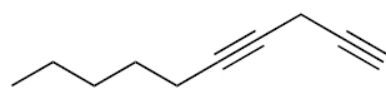

(24)

${ }^{1} \mathrm{H}$ NMR $(500 \mathrm{MHz})$

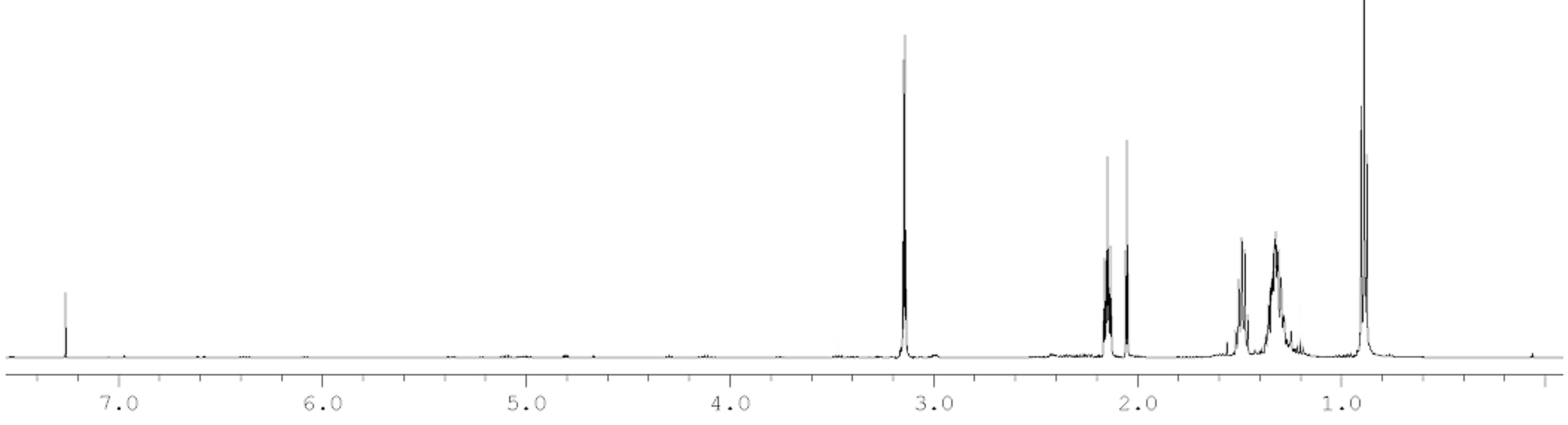

$\vec{v}$

${ }^{13} \mathrm{C}$ NMR $(125 \mathrm{MHz})$ 




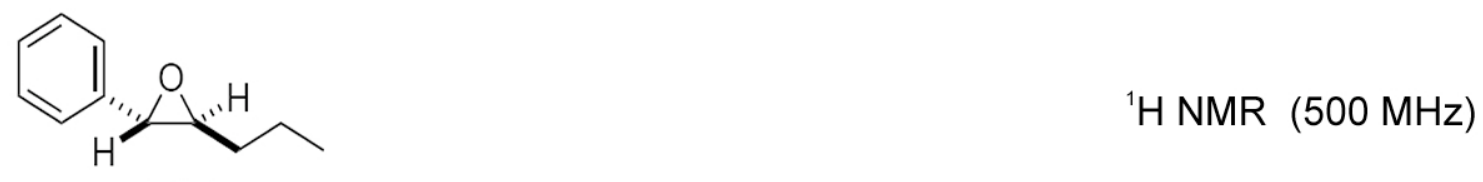

(19e)

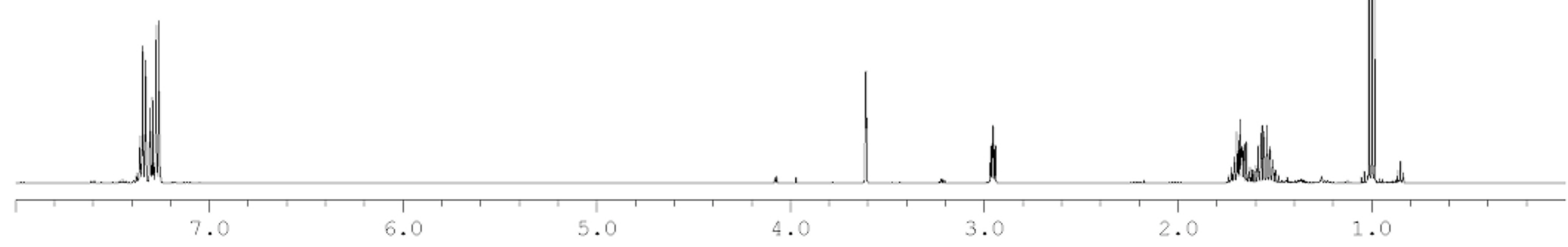

N

${ }^{13} \mathrm{C}$ NMR $(125 \mathrm{MHz})$ 
